\title{
Evaluation of Tissue Changes in the Hearts of Rats Infected with Toxoplasma Gondi
}

\author{
Hamed Najjare-Aghdam ${ }^{1}$, Arash Khaki ${ }^{2^{*}}{ }^{(}$, Yagoob Garedaghi ${ }^{3}$ \\ ${ }^{1}$ Faculty of Veterinary Medicine, Tabriz branch, Islamic Azad University, Tabriz, Iran \\ ${ }^{2}$ Department of Pathobiology, Tabriz Branch, Islamic Azad University, Tabriz, Iran \\ ${ }^{3}$ Departement of Parasitology, Tabriz Branch, Islamic Azad University, Tabriz, Iran
}

\begin{abstract}
Introduction: Toxoplasma gondii is a protozoan parasite that is globally widespread and infects humans and animals. Obligate intracellular parasites enter many organs and tissues through the bloodstream, where they invade and proliferate into cells, eventually destroying them. The aim of this study was to evaluate the extent of cardiac tissue changes in rats infected with $T$. gondii.

Methods: Male Wistar rats $(n=30)$ were allocated to three groups as follows: control group $(n=10), T_{1}$ group that received $0.3 \mathrm{~mL}$ of T. gondii tachyzoite (IP) $(n=10)$, and $T_{2}$ group that received $0.6 \mathrm{~mL}$ of $T$. gondii tachyzoite (IP) $(\mathrm{n}=10)$. However, the control group just received an equal volume of distilled water daily (IP). Animals were kept in standard condition. Forty days after inducing toxoplasmosis, heart tissues of rat in all groups were removed and prepared for histopathological examinations of heart tissue under optical microscopy after hematoxylin and eosin staining and calculation of heart tissue weight.

Results: Heart tissue weight significantly decreased in groups that received 0.3 and $0.6 \mathrm{~mL}$ of $T$. gondii tachyzoite in comparison to control groups. In histopathological studies of heart tissue under optical microscopy, atrophy and necrosis were observed in heart tissues in $T$. gondii groups.

Conclusion: Since this parasite caused necrosis of heart cells in rats in our study, it is suggested that in preventing $T$. gondii infection, health measures should be taken to promote human and animal health.

Keywords: Heart tissue, Toxoplasma gondii, Rat, Tissue changes
\end{abstract}

Received: September 25, 2019, Accepted: March 21, 2020, ePublished: April 1, 2020

\section{Introduction}

Toxoplasma gondii was first discovered in 1908 by Nicolle and Manceaux in rodents (Ctenodactylus gundi). Given that toxoplasmosis is a common disease between humans and animals, the damage caused by this disease is observed in two aspects (1). It is believed that toxoplasmosis is a disease with various forms that is often undiagnosed in humans (2). It has been reported many times that when a person complained of vision loss to several specialists and a specific test for toxoplasmosis was requested, high positive antibody titers were encountered. This parasite is an obligate intracellular protozoan found in a variety of mammals, carnivores, herbivores, birds, and rodents (3). Investigating the prevalence of toxoplasmosis in animals is of great importance from two aspects, one in terms of transmission of the disease to humans (mostly in relation to cats and feline families) and the other in terms of the economic burdens of the disease due to mortality and abortion. In recent years, most veterinarians, researchers, and economists have discovered the important role of this parasite in causing disease in humans and animals
(4). This organism is found everywhere in nature and causes various diseases that were previously assumed to be unknown (5). Toxoplasmosis is present in Iran as well as in other countries of the world and the spread of this disease in different parts of the country has been determined, which is important $(6,7)$. The first report of T. gondii in Iran was made by Ansari et al, in 1948, who succeeded in isolating the parasite from the conjunctival tissue of the eye of a 9-year-old child (8). The aim of this study was to evaluate the extent of cardiac tissue changes in rats infected with T. gondii.

\section{Materials and Methods}

RH Strain of T. gondii (a pathogenic strain) was obtained from the Department of Parasitology, School of Medicine, Tehran University of Medical Sciences. After transferring to the Faculty of Veterinary Medicine of Tabriz Azad University, it was injected intraperitoneally (IP) into rats and cultured. Wistar male rats $(n=30)$ were allocated to three groups as follows: control group $(\mathrm{n}=10), \mathrm{T}_{1}$ group that received $0.3 \mathrm{~mL}$ of $T$. gondii tachyzoite (IP) $(\mathrm{n}=10)$, 
and $\mathrm{T}_{2}$ group that received $0.6 \mathrm{~mL}$ of $T$. gondii tachyzoite (IP) $(n=10)$. However, the control group just received an equal volume of distilled water daily (IP). Animals were kept in standard condition. Forty days after the induction of toxoplasmosis, heart tissues of rat in all groups were removed and prepared for histopathological studies of heart tissue under optical microscopy after Hematoxylin and Eosin staining and calculation of heart tissue weight.

\section{Results}

Results of Histopathological Examination of Heart Tissue of Rats With Light Microscopes

In the control group, which did not receive any parasite, microscopic cross sections of cardiac tissue obtained after 40 days showed that all heart cells were normal and the blood vessels in the interstitial tissue did not show any hyperemia (Figures 1 and 2). In the groups infected with toxoplasmosis, microscopic cross-sections on day 40 showed that the blood vessels were hyperemic (Figure 3). The presence of inflammatory cells was also observed in the heart muscle and the nuclei of these muscles were swollen.

\section{Calculating the Weight of Rat Heart Tissue in Different Groups}

The mean weight of cardiac tissue was $2.2 \mathrm{~g}$ in the control group, it was $2.13 \mathrm{~g}$ in the group received $0.3 \mathrm{~mL}$ of $T$. gondii tachyzoite, and it was $2.1 \mathrm{~g}$ in the group received $0.6 \mathrm{~mL}$ of T. gondii tachyzoite. In the comparison of these groups, no statistically significant changes were seen $(P<0.05)$ (Figure 4).

\section{Discussion}

Obligate intracellular parasites enter many organs and tissues through the bloodstream, where they invade and proliferate into cells, eventually destroying them (9). Focal necrosis surrounded by eosinophils, lymphocytes, monocytes, and plasma cells is formed as a result of the

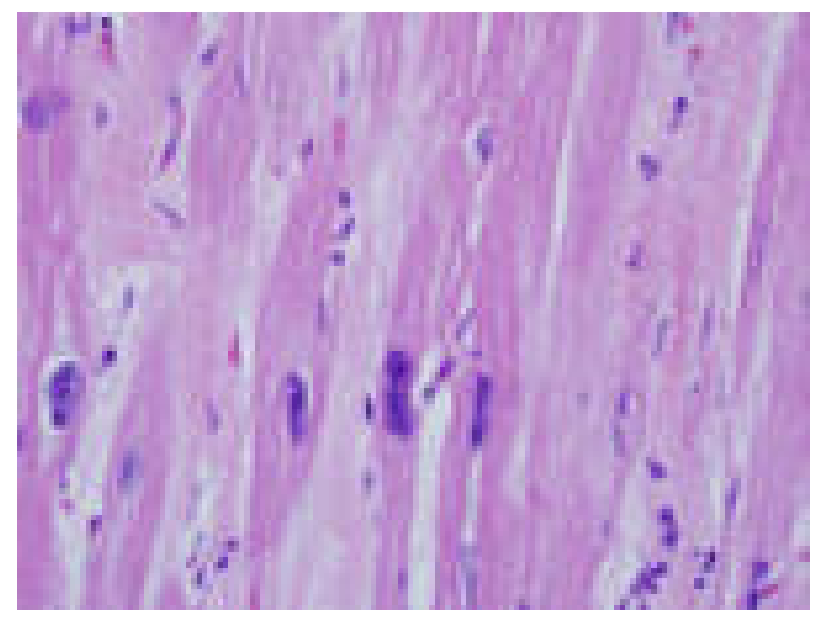

Figure 1. Cross-sectional Optical Micrograph of Heart Tissue in the Control Group after Hematoxylin and Eosin Staining $(\times 640)$.

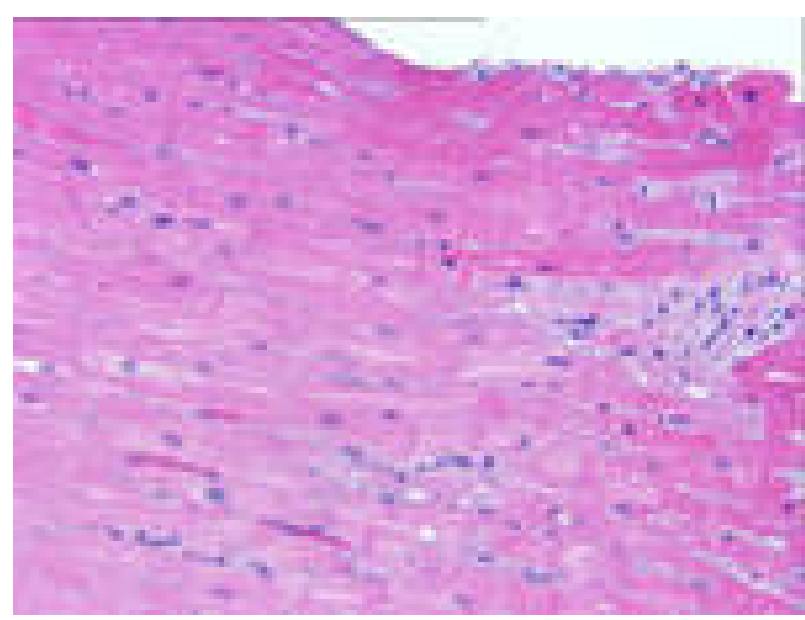

Figure 2. Photomicrograph of Cardiac Tissue in Group Received $0.3 \mathrm{~mL}$ of Toxoplasma gondii Tachyzoite. As can be seen, cardiac tissue cells are changed, note the presence of inflammatory cells after Hematoxylin and Eosin staining $(\times 640)$.

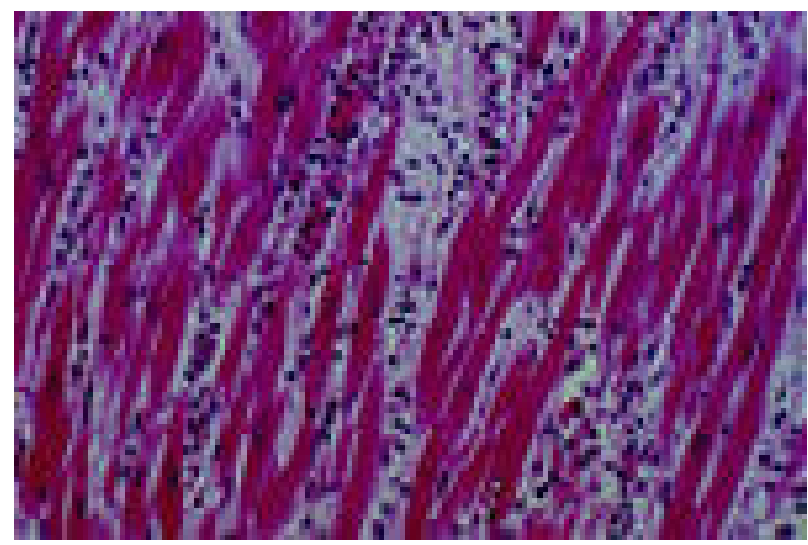

Figure 3. Photomicrograph of Cardiac Tissue in Group Received 0.6 $\mathrm{mL}$ of Toxoplasma gondii Tachyzoite. Necrotic and inflammatory cells are seen in cardiac tissues after Hematoxylin and Eosin staining $(\times 640)$.

death of infected cells (10). Cysts form in many organs, especially the brain and muscles, which may have a direct role in response to increased immunity. Toxoplasma gondii infection in most adults with sufficient immunity is asymptomatic due to the presence of extracellular antibodies and intracellular $\mathrm{T}$ cells (11). Endogenous gamma interferon is an important mediator of host resistance to T. gondii. An active infection may last much longer in the CNS and eyes than in other parts of the body (12). In the brain, small scattered necrotic areas may later be calcified to produce a distinct X-ray image. Retinochoroiditis may be either a hypersensitivity response to rupture of the cyst (often recurrent and unstable attacks) or a progressive and chronic effect of amplified tachycardia in the retina that is insufficiently an immune tissue (13).

Toxoplasmosis is found in a wide range of carnivorous, herbivorous mammals, and birds. In humans, evidence of infection has been found in all populations studied. Its 


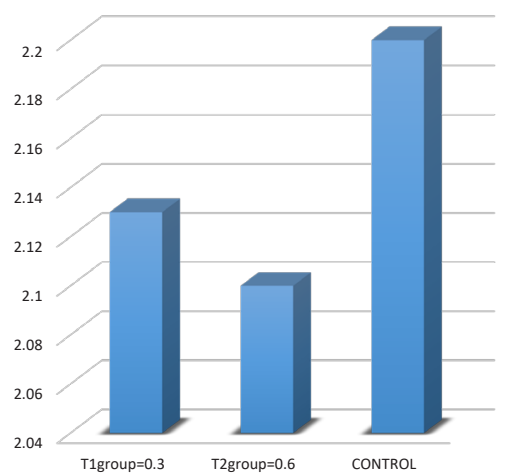

Figure 4. Changes in Heart Tissue Weight (g) in the Control and Treatment Groups.

prevalence varies from place to place for largely unknown reasons (14).

While the ingestion of meat containing cysts may be a common route of infection among carnivores, herbivores become infected by swallowing oocysts. What is probably most important epidemiologically is the observation of oocysts in cat feces that survive in the soil for 1 year (15).

Toxoplasma gondii, obtained from soil by inoculation into mice and cats, was observed during a toxoplasmosis epidemic in a rural area of Brazil (16). However, it is believed that the entire life cycle of $T$. gondii occurs only in cats. The role of domestic and wild cats in the spread of infection has not been fully evaluated (17). On Pacific islands, serological evidence of infection in the rat population depends on the presence of cats. On islands devoid of cats, there are no signs of infection in mice (18). A similar relationship has been observed between T. gondii antibodies in humans and the presence of cats in New Guinea (19).

Continental cats also contribute to the spread of infection among Colombian natives. Interestingly, in cats, the period required for ingested T. gondii to appear in the feces as oocysts depends significantly on the stage at which they are ingested $(20,21)$.

Studies have shown that in mice infected with toxoplasmosis, alkaline phosphatase activity is elevated in various tissues, including serum. Additionally, it is elevated in the serum in various diseases, especially liver, biliary, and osteoblastic diseases. However, a decrease in the activity of alkaline phosphatase is observed in some other conditions such as anemia, malnutrition, zinc deficiency, and severe liver damage $(22,23)$.

\section{Conclusion}

Since in our study this parasite caused necrosis of heart cells in rats, it is suggested that in preventing T. gondii infection, health measures should be taken to promote human and animal health.

\section{Conflict of Interests}

The authors declare that they have no conflict of interests.
Ethical Issues

In this research, ethical considerations have been fully observed.

\section{Acknowledgments}

This study was conducted under a dissertation of a Veterinary Medicine studentat Islamic Azad University, Tabriz Branch.

\section{Authors' Contribution}

AK did writing and YG editing of the manuscript. HNA designed and did data collection and statistical analysis.

\section{Funding}

This research was conducted with the support of theVice Chancellor for Research and Technology of the Islamic Azad University, Tabriz Branch.

\section{References}

1. Boothroyd JC. Toxoplasma gondii: 25 years and 25 major advances for the field. Int J Parasitol. 2009;39(8):935-946. doi:10.1016/j.ijpara.2009.02.003

2. Freyre A, Falcón J, Méndez J, Rodriguez A, Correa L, González M. Refinement of the mouse model of congenital toxoplasmosis. Exp Parasitol. 2006;113(3):154-160. doi:10.1016/j.exppara.2005.12.019

3. Elsaid MM, Martins MS, Frézard F, Braga EM, Vitor RW. Vertical toxoplasmosis in a murine model. Protection after immunization with antigens of Toxoplasma gondii incorporated into liposomes. Mem Inst Oswaldo Cruz. 2001;96(1):99-104. doi:10.1590/s0074-02762001000100011

4. Robbins JR, Zeldovich VB, Poukchanski A, Boothroyd JC, Bakardjiev Al. Tissue barriers of the human placenta to infection with Toxoplasma gondii. Infect Immun. 2012;80(1):418-428. doi:10.1128/iai.05899-11

5. Su C, Evans D, Cole RH, Kissinger JC, Ajioka JW, Sibley LD. Recent expansion of Toxoplasma through enhanced oral transmission. Science. 2003;299(5605):414-416. doi:10.1126/science.1078035

6. Cohen SB, Denkers EY. The gut mucosal immune response to Toxoplasma gondii. Parasite Immunol. 2015;37(3):108-117. doi:10.1111/pim.12164

7. Lambert H, Hitziger N, Dellacasa I, Svensson M, Barragan A. Induction of dendritic cell migration upon Toxoplasma gondii infection potentiates parasite dissemination. Cell Microbiol. 2006;8(10):1611-1623. doi:10.1111/j.14625822.2006.00735.x

8. Fuks JM, Arrighi RB, Weidner JM, et al. GABAergic signaling is linked to a hypermigratory phenotype in dendritic cells infected by Toxoplasma gondii. PLoS Pathog. 2012;8(12):e1003051. doi:10.1371/journal.ppat.1003051

9. Jacobson JM, Davidian M, Rainey PM, Hafner R, Raasch $\mathrm{RH}$, Luft BJ. Pyrimethamine pharmacokinetics in human immunodeficiency virus-positive patients seropositive for Toxoplasma gondii. Antimicrob Agents Chemother. 1996;40(6):1360-1365. doi:10.1128/aac.40.6.1360

10. Harris TH, Banigan EJ, Christian DA, et al. Generalized Lévy walks and the role of chemokines in migration of effector CD8+ T cells. Nature. 2012;486(7404):545-548. doi:10.1038/ nature11098

11. John B, Ricart B, Tait Wojno ED, et al. Analysis of behavior and trafficking of dendritic cells within the brain during toxoplasmic encephalitis. PLoS Pathog. 2011;7(9):e1002246. doi:10.1371/journal.ppat.1002246

12. Falangola MF, Petito CK. Choroid plexus infection in 
cerebral toxoplasmosis in AIDS patients. Neurology. 1993;43(10):2035-2040. doi:10.1212/wnl.43.10.2035

13. Alvarado-Esquivel C, Sánchez-Anguiano LF, MendozaLarios A, et al. Prevalence of Toxoplasma gondii infection in brain and heart by Immunohistochemistry in a hospital-based autopsy series in Durango, Mexico. Eur J Microbiol Immunol (Bp). 2015;5(2):143-149. doi:10.1556/1886.2015.00014

14. Holland GN, Engstrom RE, Jr., Glasgow BJ, et al. Ocular toxoplasmosis in patients with the acquired immunodeficiency syndrome. Am J Ophthalmol. 1988;106(6):653-667. doi:10.1016/00029394(88)90697-6

15. Watts E, Zhao Y, Dhara A, Eller B, Patwardhan A, Sinai AP. Novel approaches reveal that Toxoplasma gondii bradyzoites within tissue cysts are dynamic and replicating entities in vivo. mBio. 2015;6(5):e0115501115. doi:10.1128/mBio.01155-15

16. Dubey JP. Pathogenicity and infectivity of Toxoplasma gondii oocysts for rats. J Parasitol. 1996;82(6):951-956.

17. Berdoy M, Webster JP, Macdonald DW. Fatal attraction in rats infected with Toxoplasma gondii. Proc Biol Sci.
2000;267(1452):1591-1594. doi:10.1098/rspb.2000.1182

18. Webster JP. Rats, cats, people and parasites: the impact of latent toxoplasmosis on behaviour. Microbes Infect. 2001;3(12):10371045. doi:10.1016/s1286-4579(01)01459-9

19. Remington JS, McLeod R, Thulliez P, Desmonts G. Toxoplasmosis. In: Remington JS, Klein JO, Wilson CB, Baker CJ, eds. Infectious Diseases of the Fetus and Newborn Infant. Philadelphia: Elsevier Saunders; 2006:947-1091.

20. Beverley JK. Congenital transmission of toxoplasmosis through successive generations of mice. Nature. 1959;183(4671):13481349. doi:10.1038/1831348a0

21. Gharadaghi Y, Shojaee S, Khaki A, et al. Modulating effect of Allium cepa on kidney apoptosis caused by Toxoplasma gondii. Adv Pharm Bull. 2012;2(1):1-6. doi:10.5681/apb.2012.001.

22. Holland GN, O'Connor GR, Belfort $\mathrm{R} J \mathrm{Jr}$, Remington JS. Toxoplasmosis. In: Pepose JS, Holland GS, Wilhelmus KR, eds. Ocular Infection and Immunity. St. Louis: Mosby; 1996:11831223.

23. Su E, Honda A, Latkany P. Ocular disease due to Toxoplasma gondii. In: Weiss LM, Kim K, eds. Toxoplasma gondii: The Model Apicomplexan: Perspectives and Methods. London: Academic Press; 2014:161-192.

(C) 2020 The Author(s); This is an open-access article distributed under the terms of the Creative Commons Attribution License (http:// creativecommons.org/licenses/by/4.0), which permits unrestricted use, distribution, and reproduction in any medium, provided the original work is properly cited. 